\title{
Performance Assessment of Microenterprises Operating in the Nordic Arctic Region
}

\author{
Ville Isoherranen ${ }^{1}$ and R. M. Chandima Ratnayake ${ }^{2}$ \\ ${ }^{1}$ Kerttu Saalasti Institute, \\ University of Oulu, Finland \\ Email: ville.isoherranen@oulu.fi \\ ${ }^{2}$ Department of Mechanical and Structural Engineering and Materials Science, \\ University of Stavanger, \\ N-4036, Stavanger, Norway \\ Email: chandima.ratnayake@uis.no
}

\section{Biographical notes}

Dr. Ville Isoherranen (D.Sc. [Tech.]) is the director of Kerttu Saalasti Institute, an international research institute at the University of Oulu. He has extensive experience in international and cross-functional industrial management, including sales and marketing, supply chain management (after-sales services and sourcing), and management consulting. His research interests are strategic management, operational excellence, and customer-focused enterprises.

Dr. R. M. Chandima Ratnayake is a full-time professor at the Department of Mechanical and Structural Engineering and Materials Science at the University of Stavanger in Norway. Professor Ratnayake supervises B.Sc., M.Sc., and Ph.D. projects. He has more than 100 scientific publications in peer-reviewed journals, conference proceedings, and books.

Acknowledgements: This paper is a revised and expanded version of the paper entitled "Operational Excellence Evaluation Model for SMEs and Regional Findings" presented at the IEEE International Conference on Industrial Engineering and Engineering Management in Bali, Indonesia, on December 4-7, 2016. 


\begin{abstract}
Microenterprises provide more than $90 \%$ of the jobs in the Nordic Arctic region and are the main source of new job creation and innovation. Operations in this region can have many drawbacks related to the long distance from customers, sparse population, and climate conditions that lead to higher operation costs in comparison to other regions. Microenterprises in this region aiming for business growth must therefore pursue operational excellence to achieve a competitive advantage. Microenterprises operations development in resource constrained environment needs special approach. This study assesses the operational excellence of microenterprises in the region through 20 case studies. The performance assessments focused on order-delivery process indicators (production/manufacturing, sourcing, and sales). An operational excellence maturity review (OEMR) tool was developed to collect and analyze the data. Overall, the microenterprises obtained relatively low operational excellence scores. The review done by OEMR tool can inform initiatives for improving the competitiveness of microenterprises and their associated processes in the global market by setting practical metrics and priorities for order-deliver process development.
\end{abstract}

\title{
Keywords
}

Operational excellence, competitive advantage, maturity model, microenterprises, Nordic Arctic region

\section{Introduction}

Microenterprises form a large part of the enterprises in both developed and emerging economies. For instance, the developed Scandinavian country of Finland had a total of 283,290 enterprises in 2013 (excluding agriculture), of which 98.9\% were small- and medium-sized enterprises (SMEs) employing fewer than 50 people. In addition, 93.4\% of Finnish companies have fewer than 10 employees and can be defined as microenterprises (Yrittäjät 2017). In South Africa, which is considered one of the most prosperous countries in the African continent, micro- and small enterprises provide more than $55 \%$ of the jobs and generate $22 \%$ of the gross domestic product (Bischoff and Wood 2013; Kaufman 2007). With respect to Asia, in one of its most promising emerging economies, Indonesia, most enterprises as of 2007 were micro or small in size; these employ more than $92 \%$ of the labor force and generate about $38 \%$ of the country's gross domestic product (Sembiring 2008; Parinduri 2014). In Europe, in Cyprus, 95.5\% of the 90,905 companies employ between one and nine employees (Hadjimanolis et al. 2015). There is no universal definition of microenterprises; many definitions based on size, the number of employees, and financial turnover per annum exist (Devins et al. 2005; Roberts and Wood 2002). Based on the European Commission definition used in this study, microenterprises are companies that employ fewer than 10 people and have a turnover or balance of less than two million euros (Eurolex 2003).

In this context, the World Development Report (World Bank 2012) revealed that 600 million career opportunities must be created worldwide over the next 15 years to maintain employment rates at the existing level. Creating new career opportunities, especially in high-productivity sectors, and offering decent working conditions are some of the major responsibilities of developing and developed - that is, low- to high-income - countries (Grimm and Paffhausen 
2015). Microenterprises and SMEs will likely have a significant role in accomplishing the aforementioned target (Ayyagari, Beck, and Demirguc-Kunt 2007; Bischoff and Wood 2013).

Not much attention has been paid to microenterprises and SMEs or to performance enhancements for such enterprises even though they are recognized as significant contributors to economic growth in developed and developing countries (Novaczek and Stuart 2006; Grimm and Paffhausen 2015; Yrittäjät 2017). Furthermore, considering both developing and developed economies, the aggregate impact of entrepreneurship and microenterprises is enormous. Hence, efforts to assess the overall status of microenterprises operating in select regions are vital for determining ways to enhance their performance.

SMEs are the driving force of many regions' economies (Hausman 2005). Small companies also play an important role in supply chains (Gunasekaran et al. 2009) and can be seen as an engine and source of growth and job creation (World Bank 2013). SMEs in the Nordic Arctic context are important economic contributors and represent an interesting research focus because of their unique conditions. A renewed focus on SMEs is relevant, as they constitute the economic basis of many nations and foster innovation, provide employment, and increase competitiveness and global economic growth (Taneja, Pryor, and Hayek 2016; Claudino et al. 2017). The status of SMEs can be evaluated by focusing on either internal or external factors.

Performance assessments of microenterprises can provide essential data and baseline information on the status of operational processes and internal capabilities. The results of such assessments can then be used to enhance the competitiveness - that is, the order-delivery processes — of these enterprises (Isoherranen et al. 2016). To deliver innovations to market and to create growth and employment, microenterprises need to be able to operationalize their strategies in cost-efficient and effective ways, as they have resource constraints that have been recognized in previous studies (e.g., Dutta and Evrard 1999; Kelliher and Reinl 2009). To this end, internal factors, skills, processes, and operations should be analyzed in a systematic way. In this study, we evaluated the operational excellence of 20 case study companies using an operational excellence maturity model.

\section{Background and industrial challenges}

\section{Challenges resulting from Nordic Arctic conditions}

Although the Nordic Arctic region is rich in natural resources, most parts of the region, as well as areas of Norway, Sweden, and Finland, are constrained by difficult weather conditions (Ratnayake 2016; Kayrbekova 2011). Opportunities for effective industrial operations are further constrained by several factors, including demographic changes, peripherality, and distance from markets (Olsen et al. 2016). Moreover, factors such as remote location, limited transport infrastructure, harsh climate, and high global prices for commodities lead to higher production/manufacturing and distribution costs in this region (Ratnayake 2016). Due to significant requirements for capital, research and development, and other knowledge-intensive stages of production/manufacturing, further processing of resources inherently tends to move outside the Arctic region (Olsen et al. 2016). In this context, high capital requirements are associated with harsh weather conditions, which are related to higher energy consumption, thereby diminishing the ability to reduce production/manufacturing costs (Olsen et al. 2016). The reasons for higher operational costs in the Nordic Arctic region can be divided into materials and equipment, work processes, support services and logistics, and operational philosophy and support and maintenance strategies (Ratnayake 2016; Kayrbekova 2011). 
- Materials and equipment. Materials, equipment, lubricants, and fluids need to be suitable for the low temperatures and harsh weather conditions of the Arctic climate. These conditions necessitate engineering or design choices of higher cost that should be as environmentally friendly as possible because of the environmental sensitivity of this region.

- Work processes. The physical factors of the Arctic climate, such as low temperature, snow, wind, ice, and darkness, diminish the maintainability, supportability, and availability of industrial systems and equipment, resulting in reduced production/manufacturing performance and profitability.

- Support services and logistics. The delivery and storage of raw materials, finished products, and machinery spare parts as well as the transportation of personnel can require more time compared to operations under ordinary weather conditions.

- The operational philosophy and the support and maintenance strategies for production/manufacturing plants must involve special considerations in the Nordic Arctic region (compared to the best available technology developed for operations in an ordinary region), as machineries require modifications or costly technological solutions.

Hence, it is vital to investigate the status of microenterprises to provide more effective and efficient solutions that would allow them to achieve higher operational excellence.

\section{Performance, operational excellence, and maturity}

The current challenging economic situation in Finland and in Europe calls for actions to improve the competitiveness of companies so that they can succeed in the global market. Universities and research institutions in particular have been called upon to engender a positive impact on society. This duty has been specifically outlined in Finnish University Law as the "third mission of universities" (the other tasks being providing the highest level of teaching and research; Finland University Act 2009). The location of Kerttu Saalasti Institute, an international research institute, at the University of Oulu in Northern Finland in the northern sparsely populated area (NPA) means that this institute forms an appropriate research environment for investigating themes common to this area. This area is sparsely populated, and long distances must be traversed to reach major customers, customer sites, or large cities. Also, the harsh and cold climate of the Nordic Arctic combined with the high cost of living produce high operating costs for companies. Thus, companies must develop competitive advantages from the perspective of operational excellence - that is, they must execute processes and deliveries at the lowest cost and the highest quality possible-because other traditional competitive advantages are hard to create. A successful strategy for obtaining business performance can thus be based on achieving greater operational excellence.

\section{Operational excellence}

Gleich and Sauter (2008) interpreted operational excellence as the development of enablers to generate competitive benefits in a dynamic environment based on the resources of an organization (adaptability). The development of these enablers is achieved through continuous improvement, and the continuous improvement is dynamic capability, which develops the core processes. In this context, Gleich and Sauter (2008) identified six fields that are essential for long-term "operational" success (Figure 1). 


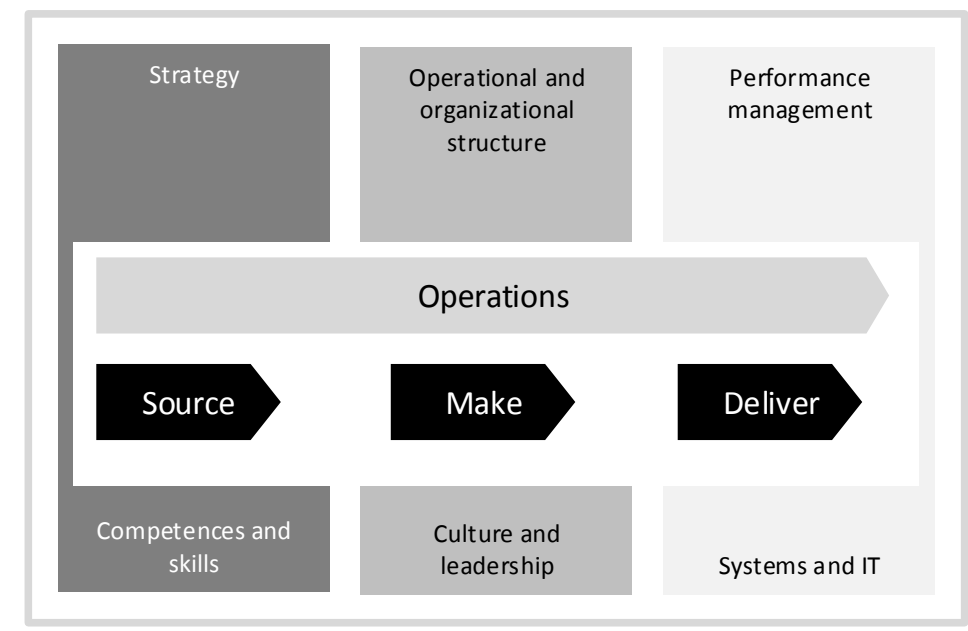

\section{Figure 1: The six fields essential for long-term operational excellence (Gleich and Sauter 2008)}

In general, operational excellence is achieved by maximizing customer value, which is delivered through operations (Sutton 2011). This means that an operational excellence strategy is about the pursuit of leading the industry in price and convenience (Treacy and Wiersema 1993). Companies that are trying to achieve operational excellence look for ways to minimize overhead costs, eliminate intermediate production steps, reduce "friction" costs, and optimize processes across functions and departments (Treacy and Wiersema 1993). The pursuit of operational excellence needs strong leadership, empowerment of people, learning and adoption of best practices, and value-adding technology solutions (Sutton 2011). For microenterprises, the journey towards operational excellence requires a focus on the essentials, with limited resources available for development efforts. Well-functioning operations can produce significant competitive advantage and business performance, as well as help in the pursuit of an optimum competitive stance in the operating environment. Customers can see this excellence in, for instance, short lead times and quick and reliable deliveries (Olhager and Persson 2006). The linkage of operational excellence to performance has been widely discussed (e.g., Sadun, Bloom, and Van Reenen 2017), and the importance of a measurement system for the development of operational excellence has been presented by various scholars (e.g., Basu 2004; Oakland 2014; Evans and Jack 2003; Cook and Verma 2002). Overall, it can be stated that higher levels of maturity in business processes will result in better control of results, the improved ability to forecast performance, and the ability to set new, higher goals for performance (Lockamy and McCormack 2004b). The linkage of the operational excellence approach to business performance and to quality awards such as the Malcolm Baldrige National Quality Award has also been discussed by Evans and Jack (2003). Companies that pursue operational excellence have better business performance and capability to adapt to changes in the market - that is, they have higher business resilience. Although Porter (1996) claimed that sustainable operational effectiveness cannot be based on competitive advantage, the latest research of Sadun, Bloom, and Van Reenen (2017) showed the strong linkage of operational excellence to strategic success and, contrary to Porter's (1996) statement, the hard-to-copy sustainable competitive advantage of operational excellence.

Gleich and Sauter (2008) also presented an approach elaborating on the term "operations excellence" in relation to three levels: strategy (guiding towards best practices), performance improvement (revitalizing performance drivers and competitive levers), and enablers (organization, processes, IT, key performance indicators, etc.). Moreover, Jaeger, Matyas, and Sihn (2014) developed an operations excellence assessment framework and a methodology to 
identify critical root-cause relationships. In this context, according to Sutton (2011) operations excellence means focusing strategically on maximizing the value that operations deliver to customers, through strong leadership, the power of people, the use of industry best practice and the application of value-add technologies.

The capability for integration at the intra- and interorganizational levels based on the evolved technology plays a vital role in achieving higher operational excellence. Integration at the intraorganizational level within a firm, for instance, occurs between production, logistics, and marketing (that is, at the cross-functional flows as well as at the behavioral, communicational, and interactive flows; Morash and Clinton 1998; Asif et al. 2010). It also requires balancing the firm's intraorganizational integration, which focuses on the "collaborative closeness of relationships with both outside customers and suppliers including partnerships and strategic alliances" (Morash and Clinton 1998; Asif et al. 2010). The integration capability and resulting return on investments from such an integration are dependent on the maturity level of the technology (and/or approaches). The role of inter- and intraorganizational integration as well as technology evolution is presented in Figure 2.

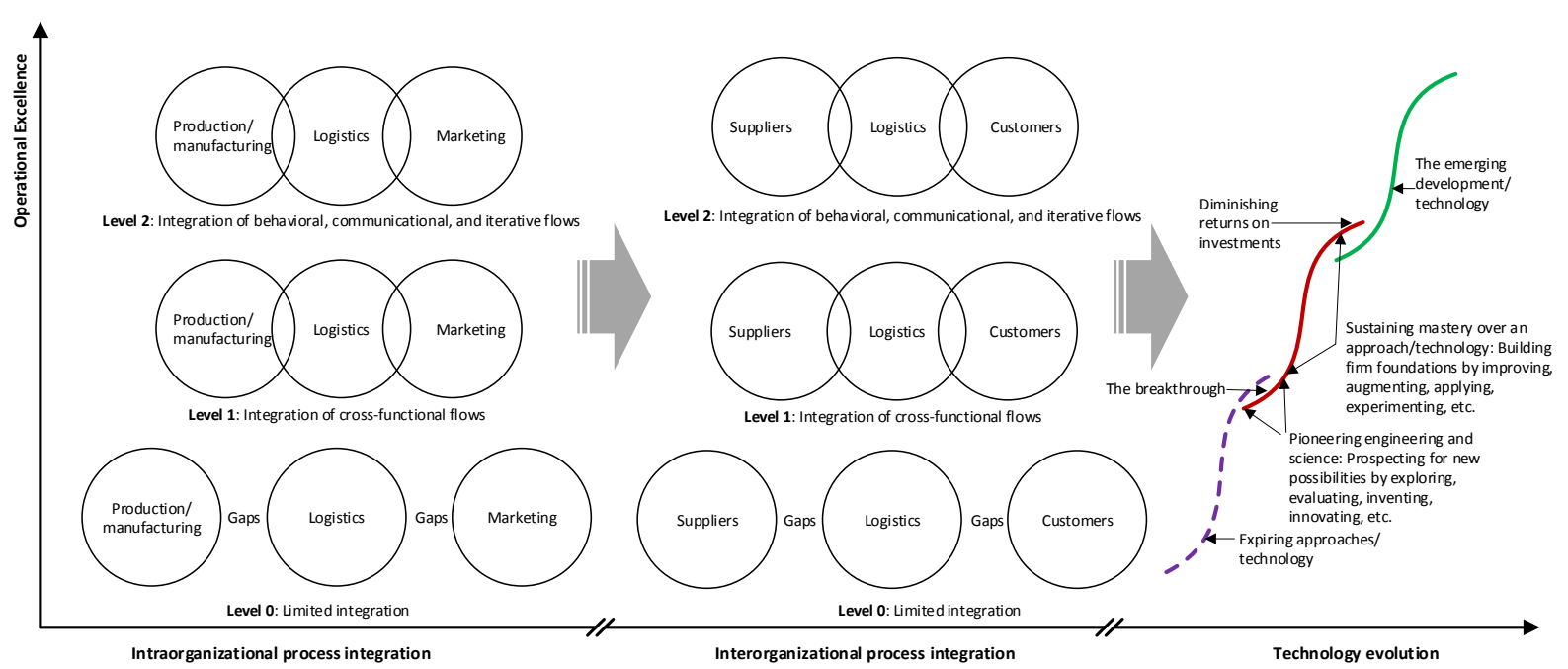

Figure 2: Operational excellence from the intra- and interorganizational and technology (and/or approaches) evolution perspective (adapted from Simmonds [2009] and Morash and Clinton [1998])

Several models are available for operational excellence assessment, such as the Shingo Assessment (Miller 2014), the European Foundation for Quality Management Excellence Model (EFQM 2012), the Malcom Baldrige National Quality Award (MBOA 2016), Kobayashi's (1995) 20 Keys of Workplace Improvement, Lean Enterprise Self-Assessment (LESAT; Nightingale 2005), Rapid Plant Assessment (Goodson 2002), and Good-to-Great Assessment (Collins 2006). The majority of the existing assessment tools focus on the process improvement and results dimensions of operational excellence (Rusev and Salonitis 2016), whereas the Shingo assessment tool covers all four dimensions: culture, process improvement (aligned with continuous improvement; Bessant, Caffyn, and Gallagher 2001), enterprise alignment, and results (Miller 2014). Rusev and Salonitis (2016) revealed that lean principles with the organizational culture and management at a strategic level enable the enhancement of operational excellence beyond the use of individual tools and techniques. 
To develop operational excellence, it is important to understand operational-level activities. To manage operational excellence, it is essential to develop and deploy a measurement system. The literature review reveals that it is important to take inter- as well as intraorganizationallevel performance into consideration in operational excellence assessment. Furthermore, no proper maturity model (that is, a model that can take intra- and interorganizational factors into consideration) was found in previous research for the microenterprise scale or for the NPA region given its unique characteristics and context-specific challenges (Isoherranen et al. 2016). Microenterprises have not traditionally been at the center of academic research and require a unique research approach, which is presented in the following sections.

\section{Maturity}

Generally, the term "maturity" refers to the state of being "fully developed" or "perfected" (Tahri and Drissi-Kaitouni 2015). The concept of maturity has been used to describe the state of an organization's effectiveness (Crawford 2006, Becklund, Chronéer, and Sundqvist 2014). In this context, the term "maturity" refers to a state where an organization is in a "perfect" (or "fully developed") condition to achieve its objectives (Cooke-Davies 2004a). The "maturity level" refers to "grouped capabilities that describe increasingly greater orders of consistency, visibility, and control within the organization" (Schlichter and Duncan, 1999). The lowest maturity level is usually ad hoc or least defined, which might represent dimensions related to processes and practices. On the other hand, the highest level requires intelligent feedback that may be related to a continuous improvement process. A number of "maturity models" are being developed to assess (either directly or indirectly) how mature the selected organization is (Cooke-Davies 2004b).

\section{Maturity models}

Several maturity models have been developed based on the need in a particular industrial application. Table 1 illustrates examples of some of these maturity models.

Table 1

\section{Examples of maturity models}

\begin{tabular}{|c|c|c|}
\hline Instrument name/author & Details & Remarks \\
\hline $\begin{array}{lr}\text { Lean } & \text { Manufacturing: } \\
\text { Performance } & \text { Evaluation } \\
\text { Audit (Donovan 2015) }\end{array}$ & $\begin{array}{l}\text { It consists of a number of yes/no questions } \\
\text { focusing on several fields important in the } \\
\text { lean management approach: process } \\
\text { planning and control, management and } \\
\text { leadership, quality control and planning, } \\
\text { suppliers, selected lean techniques, } \\
\text { customer focus, and performance } \\
\text { improvement. }\end{array}$ & $\begin{array}{l}\text { The tool is a checklist for the assessment of an } \\
\text { organization's status and ongoing progress in } \\
\text { adopting lean manufacturing criteria. }\end{array}$ \\
\hline Lean Index (Ray et al. 2006) & $\begin{array}{l}\text { It is a set of indices specifying performance } \\
\text { typical for lean transformation, such as } \\
\text { productivity measured in product volume } \\
\text { per labour hour and energy consumption } \\
\text { per labour hour. }\end{array}$ & $\begin{array}{l}\text { It is used to give a company feedback on the } \\
\text { leanness of its operations and to prioritize lean } \\
\text { efforts. It is intended for use in the wood } \\
\text { products industry. }\end{array}$ \\
\hline $\begin{array}{l}\text { Capability Maturity Model } \\
\text { (CMM; Hutchings 2001) }\end{array}$ & $\begin{array}{l}\text { CMM provides guidance for managing, } \\
\text { measuring, and monitoring software } \\
\text { development processes and helps } \\
\text { organizations improve their software } \\
\text { development processes for both products } \\
\text { and services by describing characteristics } \\
\text { of best practices (Tahri and Drissi-Kaitouni } \\
\text { 2015). }\end{array}$ & $\begin{array}{l}\text { This model was developed and popularized by } \\
\text { the Software Engineering Institute at Carnegie } \\
\text { Mellon University and used for software } \\
\text { development (Tahri and Drissi-Kaitouni 2015). }\end{array}$ \\
\hline $\begin{array}{l}\text { Test Process Improvement } \\
\text { (TPI) Model (Koomen and } \\
\text { Pol 1998) }\end{array}$ & $\begin{array}{l}\text { The TPI model supports the improvement } \\
\text { of test processes. It offers insight into the }\end{array}$ & $\begin{array}{l}\text { The model helps define gradual and controllable } \\
\text { improvement steps. }\end{array}$ \\
\hline
\end{tabular}




\begin{tabular}{|c|c|c|}
\hline Instrument name/author & Details & Remarks \\
\hline & $\begin{array}{l}\text { "maturity" of the test processes within the } \\
\text { organization. }\end{array}$ & \\
\hline $\begin{array}{lr}\text { Portfolio, } & \text { Program, and } \\
\text { Project } & \text { Management } \\
\text { Maturity } & \text { (P3M3) Model } \\
\text { (P3M3-OGC 2006) }\end{array}$ & $\begin{array}{l}\text { P3M3 is an improved version of the Project } \\
\text { Management Maturity Model, based on the } \\
\text { process maturity framework that evolved } \\
\text { into the Software Engineering Institute's } \\
\text { CMM. }\end{array}$ & $\begin{array}{l}\text { The development of a descriptive reference } \\
\text { model would be beneficial in providing } \\
\text { organizations with more effective guidance for } \\
\text { establishing process improvement programs. }\end{array}$ \\
\hline $\begin{array}{l}\text { Organizational Project } \\
\text { Management Maturity Model } \\
\text { (OPM3; Knowledge } \\
\text { Foundation 2003) }\end{array}$ & $\begin{array}{l}\text { OPM3 enables organizations to bridge the } \\
\text { gap between organizational strategy and } \\
\text { successful projects (Tahri and Drissi- } \\
\text { Kaitouni 2015). }\end{array}$ & $\begin{array}{l}\text { This model identifies a number of best practices } \\
\text { that facilitate the path of organizational maturity } \\
\text { (Tahri and Drissi-Kaitouni 2015). }\end{array}$ \\
\hline $\begin{array}{l}\text { Lean Enterprise } \quad \text { Self- } \\
\text { Assessment Tool } \\
\text { (LESAT; Nightingale } \\
\text { Mize 2002) }\end{array}$ & $\begin{array}{l}\text { LESAT is composed of three sections: (1) } \\
\text { lean transformation/leadership, or the } \\
\text { processes and leadership supporting lean } \\
\text { transformation; (2) life cycle processes, } \\
\text { including product development from } \\
\text { conception to after-sales service; and (3) } \\
\text { enabling infrastructure, namely processes } \\
\text { responsible for resources enabling } \\
\text { company operations. }\end{array}$ & $\begin{array}{l}\text { This self-assessment tool was designed to } \\
\text { improve the degree of leanness and provide } \\
\text { feedback for improvement. }\end{array}$ \\
\hline $\begin{array}{l}\text { Lean Construction Maturity } \\
\text { Model (LCMM; Nesensohn } \\
\text { et al. 2014) }\end{array}$ & $\begin{array}{l}\text { LCMM has } 11 \text { key attributes: (1) lean } \\
\text { leadership, (2) customer focus, (3) way of } \\
\text { thinking, (4) culture and behaviour, (5) } \\
\text { competencies, (6) improvement enablers, } \\
\text { (7) processes and tools, ( } 8 \text { ) change, (9) } \\
\text { work environment, (10) business results, } \\
\text { and (11) learning and competency } \\
\text { development. }\end{array}$ & $\begin{array}{l}\text { The model provides organizations with an } \\
\text { assessment of the state of their lean } \\
\text { construction journey. }\end{array}$ \\
\hline
\end{tabular}

Although tools have been developed to assess organizations' maturity, most of them address the intraorganizational level. Therefore, a tailor-made approach was developed to assess the operational excellence maturity performance of microenterprises operating in the Nordic Arctic region, enabling intra- and interorganizational factors (sales, sourcing, and production processes) to be included in the analysis.

\section{Maturity levels utilized in the study}

The maturity level of each process factor was determined on a scale of one to five. Level 1 corresponds to an "ad hoc" level of operations. Level 2 indicates a "defined" maturity level, level 3 is a "controlled" maturity level, and level 4 is an "optimized" maturity level. Finally, level 5 corresponds to "continuous improvement." A company has to pass through all lower levels of maturity to reach level 5, which corresponds to operational excellence (Isoherranen et al. 2016). Table 2 illustrates the maturity levels used in the study and their corresponding descriptions. 
Table 2

Maturity levels utilized in the study

\begin{tabular}{ll}
\hline Maturity level & \multicolumn{1}{c}{ Description } \\
\hline Level 1 & $\begin{array}{l}\text { Level 1 denotes a very low level of process definition wherein processes are largely separated. The } \\
\text { management is based on individual styles, and no systematic management system is in place. No data are } \\
\text { collected on the performance process. }\end{array}$ \\
\hline Level 2 & $\begin{array}{l}\text { In level 2, there is some level of process definition, but it is not systematically documented. Process } \\
\text { integration has begun, and the aim is to create a stable environment to ensure the reliability and } \\
\text { effectiveness of processes. }\end{array}$ \\
\hline Level 3 & $\begin{array}{l}\text { In level 3, the whole company is involved in defining processes, and these are documented. The metrics for } \\
\text { process performance, derived from customer requirements, have been defined. The collected data are } \\
\text { analyzed to refine and improve processes. Process ownership has been defined. Core processes have a } \\
\text { common method for information sharing. }\end{array}$ \\
\hline Level 4 & $\begin{array}{l}\text { In level 4, the process data are collected and statistically analyzed. This leads to process flow optimization } \\
\text { and standardized process steps. The metrics are derived from the company's strategy and customers' } \\
\text { requirements. Resource allocation and prioritization are based on what is best and most efficient for the } \\
\text { company as a whole. }\end{array}$ \\
\hline Level 5 & $\begin{array}{l}\text { In level 5, continuous improvement has become part of the company culture and mode of operations. The } \\
\text { scope of improvement has expanded to cover partner companies in the supply network, and the order- } \\
\text { delivery process is optimized for the customer. Metrics to evaluate the processes are derived from the } \\
\text { company's strategies and the end customers' requirements. Management is based on process } \\
\text { management, and the aim is to build an intelligent operations network. }\end{array}$ \\
\hline
\end{tabular}

\section{Methodology}

\section{Research approach, work process, and data collection}

Sales, sourcing, and production were selected as the main indicators to use in the operational excellence maturity review (OEMR) model, as these represent the main aspects of the orderdelivery process and take into account the target group of microenterprises, which mostly employ fewer than 10 people. This model allows for a highly efficient measurement approach that can easily but accurately provide results on the status of operational excellence. The OEMR model was built after a careful literature review in which the existing models were examined. A summary of this examination is presented in Table 3, which indicates the aspects on which the OEMR model is based. None of the current models could be used due to the special context of microenterprises. All the examined models had been designed for large corporations, and the microenterprises' resource-constrained operating environment called for an efficient and fast maturity review model. For instance, the Supply Chain Management Maturity Model (Lockamy and McCormack 2004a) derived from the Supply Chain Operations Reference Model was designed for large enterprises and focuses on the supply chain part of the company's processes. Previous research has shown low maturity for SMEs (Töyli et al. 2008) when using these models with large corporations' processes as a design driver. The models examined in the literature review were the Capability Maturity Model Integration (CMMI), Hammer's model, Object Management Group (OMG) Business Process Model Notation (BPMN), Harmon's model, and Fisher's model. The process factors, which are the building blocks of each of the dimensions, were derived from the literature review (Table 3. 
Table 3

Summary of the literature synthesis informing the operational excellence maturity review model

\begin{tabular}{ll}
\hline Process factors & \multicolumn{1}{c}{ Sources } \\
\hline 1. Process status & CMMI, Hammer, Harmon, OMG BPMM \\
2. Personnel skills & Fisher, Hammer \\
3. Process optimization & CMM, OMG BPMM, Harmon \\
4. Process control & CMM, OMG BPMM, Harmon \\
5. Process performance management & CMM, OMG BPMM, Harmon, Hammer, Fisher \\
6. Knowledge transfer and IT systems & Harmon, Fisher, Hammer, OMG BPMM \\
\hline
\end{tabular}

(adapted from Isoherranen et al. 2016)

Notably, microenterprises are unable to extensively invest time or effort in operational reviews or assessments. The development of the maturity model was an iterative process that began with an extensive model (OEMR v1.0), which was based on the maturity models found in the literature review. This model was first tested with 10 companies, and the observations from this testing indicated that the model needed to be simplified because it required companies to invest a lot of time and key resources. In the testing setup, the researcher visited the companies and facilitated the interviews based on the maturity model v1.0 content. These interviews could not be completed in one working day due to the model complexity and details. During these interviews, it was clearly noted that the request from the companies was to develop a model that could be applied within two hours and thus needed fewer resources yet still gave reliable and actionable results (benefit vs. effort). Based on these practical testing rounds, the current version of the OEMR tool (OEMR v2.1) was developed, which considers three order-delivery process performance dimensions:

1. The sales process comprises three subprocesses: sales and marketing, order handling, and customer service. Sales and marketing considers customers, target segments, product and service offerings, and prices, as well as the deployment and management of go-to-market campaigns. Order handling deals with sales orders, sales registration, order confirmations, and shipment and logistics tracking. Customer service contemplates customer interaction (Q\&A), problem solving, and overall communication.

2. The sourcing process comprises two subprocesses: material handling and inventory management. Material handling relates to supplier selection and evaluation as well as the actual purchase process. Inventory management deals with handling the material, stock management, and optimization processes.

3. The production process comprises three subprocesses: production planning, manufacturing, and material delivery. Production planning considers both production scheduling and planning. Manufacturing is the actual process in which production inputs (such as materials) are transformed into actual products, involving several steps and phases that are linked to the actual production flow and value stream. Material delivery deals with 
the raw material inputs to the manufacturing process and the logistics of the ready products/goods up through shipment.

Each of the three order-delivery process performance dimensions are then divided into six process factors (Table 3). These process factors were based on the extensive literature synthesis that the OEMR model was built upon. The process factors are 1) process status, 2) personnel skills, 3) process control, 4) process performance management, 5) process optimization, and 6) knowledge transfer and IT.

Table 4

Description of 20 case companies

\begin{tabular}{|c|c|c|}
\hline \multirow[b]{2}{*}{$\begin{array}{l}\text { Case } \\
\text { company \# }\end{array}$} & \multicolumn{2}{|c|}{ Description } \\
\hline & Industry & $\begin{array}{c}\text { Revenue category } \\
\text { (million EUR) }\end{array}$ \\
\hline 1 & Machinery & $2-10$ \\
\hline 2 & Waste and materials recovery & $2-10$ \\
\hline 3 & Metal & $2-10$ \\
\hline 4 & Metal & a \\
\hline 5 & Metal & $0.4-0.999$ \\
\hline 6 & Food & $2-10$ \\
\hline 7 & Metal & a \\
\hline 8 & Wood & $2-10$ \\
\hline 9 & Machinery & $1-2$ \\
\hline 10 & Motor vehicles & $10-20$ \\
\hline 11 & Food & $1-2$ \\
\hline 12 & Retail trade & $0.1-0.199$ \\
\hline 13 & Food & $10-20$ \\
\hline 14 & Metal & $10-20$ \\
\hline 15 & Wholesale and retail trade & $2-10$ \\
\hline 16 & Metal & $0.4-0.999$ \\
\hline 17 & Retail trade & $2-10$ \\
\hline 18 & Wood & $0.4-0.999$ \\
\hline 19 & Repair and installation & $2-10$ \\
\hline 20 & Furniture & $20-30$ \\
\hline
\end{tabular}

\section{(adapted from Isoherranen et al. 2016)}

The selection of 20 case companies was based on replication logic, as multiple cases would result in a more robust study and provide more compelling results (Yin 2009). The selection of similar cases also enables relevant results. The 20 case companies were selected among micromanufacturing enterprises in the Finland NPA region. In Table 4, these case companies are listed based on their industry category and revenue category. The selection criteria were that the enterprise must be operating at a micro to small scale and that the manufacturing location and headquarters be in the NPA region. The companies were selected from various industry areas, including metal and wood products manufacturing. 
Data were collected using our newly developed OEMR tool v2.1 (Excel-based) through interviews with the case companies. The researchers visited the case companies and held review meetings at the company premises. The rationale for selecting this interview-based research approach and not an online survey or something similar was the same as that of Söderberg and Bengtsson (2010) and Töyli et al. (2008): the understanding of the concept of maturity and maturity models is low within microenterprises, which could lead to missing information or wrong information due to misunderstandings. The interview approach would also ensure that all the relevant information for determining the case company maturity could be obtained, as the questions could be explained in more detail, a score could be set for the case company, and certain information would not be lacking. Introductory material on the project and the OEMR tool were sent beforehand to company representatives so that they could prepare themselves.

The interviews began with a short introduction on maturity model logic and an explanation of the overall purpose and structure of the tool. After this introduction, a question-and-answer session was held to ensure that company representatives had a sufficient understanding of the maturity review logic; this was essential because the microenterprises were not familiar with the maturity concepts. After this, the maturity review was initiated by going through the steps of the maturity model tool, starting with the first dimension (sales) and its first process factor (process status). For each process factor, the maturity level (1 to 5) was scored according to statements; the interviewees selected the statement that was most fitting for the company. The remaining sales process factors were similarly evaluated in order. Then, all six process factors were completed for the sales dimension, and the review moved on to the production dimension and finally to the sourcing dimension of the OEMR model. The whole review was completed within about two hours, which was an essential design prerequisite of the OEMR tool. A 100\% answer ratio was achieved, and there was no missing data from the 20 case companies. The work process of the research study is illustrated in Figure 3.

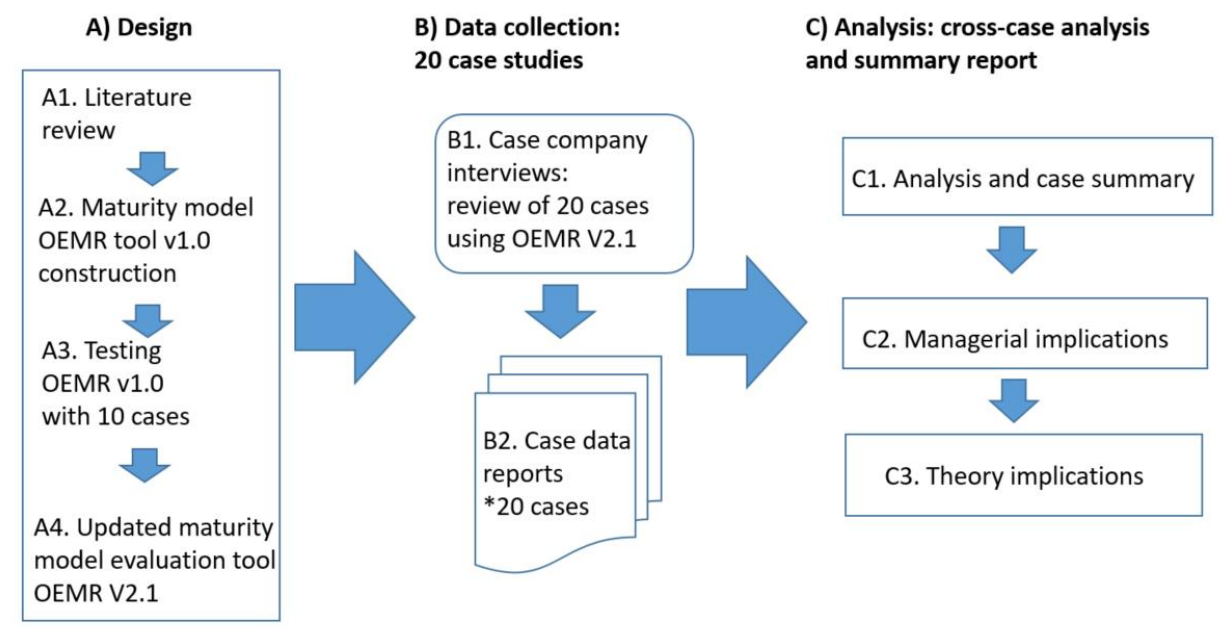

Figure 3: Research work process 


\section{Results and analysis}

Table 5 presents the data collected from 20 case companies on their sales, sourcing, and manufacturing/production processes in order to review their operational excellence. The 20 case companies are indicated in the columns of the table. Each process is divided into six process factors. The average score for each of these factors is then used to give a single value for the dimension.

Table 5

Data collected on the operational excellence performance of the 20 case companies

\begin{tabular}{|c|c|c|c|c|c|c|c|c|c|c|c|c|c|c|c|c|c|c|c|c|}
\hline Microenterprise & 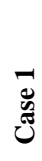 & 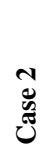 & $\begin{array}{l}m \\
\tilde{y} \\
\tilde{W}\end{array}$ & 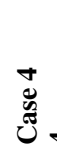 & $\begin{array}{l}n \\
0 \\
0 \\
\tilde{E} \\
\tilde{E}\end{array}$ & $\begin{array}{l}0 \\
\vdots \\
\tilde{U} \\
\tilde{N}\end{array}$ & 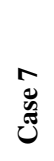 & 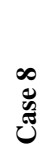 & $\begin{array}{l}\hat{y} \\
\text { चु } \\
\text { चु }\end{array}$ & 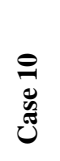 & 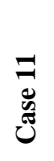 & $\frac{\mathfrak{Z}}{\widetilde{J}}$ & 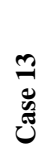 & 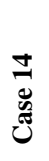 & 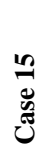 & $\begin{array}{l}0 \\
0 \\
\tilde{z} \\
\tilde{z} \\
0\end{array}$ & $\frac{D}{\tilde{D}}$ & 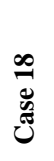 & 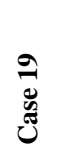 & 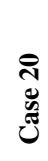 \\
\hline \multicolumn{21}{|l|}{ Sales } \\
\hline Process status & 2 & 2 & 3 & 4 & 1 & 2 & 2 & 1 & 1 & 2 & 1 & 1 & 2 & 2 & 3 & 2 & 3 & 2 & 3 & 2 \\
\hline Personnel skills & 2 & 2 & 4 & 4 & 2 & 3 & 2 & 2 & 1 & 2 & 2 & 2 & 2 & 2 & 3 & 2 & 2 & 2 & 3 & 2 \\
\hline Process control & 2 & 3 & 3 & 3 & 2 & 3 & 2 & 1 & 2 & 2 & 1 & 1 & 2 & 2 & 2 & 2 & 3 & 2 & 3 & 2 \\
\hline Process performance management & 2 & 3 & 3 & 3 & 1 & 3 & 2 & 1 & 2 & 1 & 2 & 2 & 2 & 3 & 2 & 3 & 4 & 2 & 3 & 2 \\
\hline Process optimization & 1 & 3 & 2 & 2 & 1 & 2 & 2 & 1 & 1 & 2 & 2 & 2 & 2 & 3 & 2 & 2 & 2 & 2 & 3 & 1 \\
\hline Knowledge transfer \& IT & 1 & 3 & 3 & 2 & 4 & 2 & 2 & 2 & 1 & 2 & 1 & 1 & 2 & 2 & 2 & 4 & 5 & 2 & 4 & 1 \\
\hline Average score & 2 & 3 & 3 & 3 & 2 & 3 & 2 & 1 & 1 & 2 & 2 & 2 & 2 & 2 & 2 & 3 & 3 & 2 & 3 & 2 \\
\hline \multicolumn{21}{|l|}{ Sourcing } \\
\hline Process status & 3 & 3 & 3 & 3 & 2 & 3 & 3 & 1 & 2 & 2 & 1 & 1 & 3 & 2 & 3 & 2 & 2 & 2 & 3 & 2 \\
\hline Personnel skills & 3 & 3 & 3 & 2 & 2 & 4 & 3 & 1 & 2 & 2 & 2 & 2 & 2 & 2 & 3 & 2 & 2 & 2 & 4 & 2 \\
\hline Process control & 2 & 4 & 3 & 2 & 1 & 3 & 2 & 1 & 2 & 1 & 1 & 1 & 2 & 2 & 2 & 3 & 2 & 2 & 3 & 1 \\
\hline Process performance management & 2 & 4 & 2 & 2 & 2 & 3 & 2 & 2 & 2 & 1 & 1 & 1 & 2 & 2 & 2 & 1 & 3 & 2 & 3 & 2 \\
\hline Process optimization & 2 & 3 & 2 & 2 & 2 & 2 & 2 & 2 & 2 & 2 & 1 & 2 & 2 & 2 & 2 & 2 & 2 & 2 & 4 & 2 \\
\hline Knowledge transfer \& IT & 3 & 4 & 3 & 4 & 4 & 3 & 3 & 1 & 2 & 2 & 1 & 1 & 3 & 3 & 2 & 4 & 4 & 1 & 4 & 3 \\
\hline Average score & 3 & 4 & 3 & 3 & 2 & 3 & 3 & 1 & 2 & 2 & 1 & $\mathbf{1}$ & 2 & 2 & 2 & 2 & 3 & 2 & 4 & 2 \\
\hline \multicolumn{21}{|l|}{ Manufacturing/production } \\
\hline Process status & 2 & 3 & 2 & 3 & 3 & 4 & 2 & 1 & 1 & 2 & 2 & 1 & 3 & 2 & 2 & 2 & 4 & 2 & 3 & 2 \\
\hline Personnel skills & 2 & 3 & 3 & 3 & 2 & 3 & 2 & 1 & 2 & 2 & 2 & 2 & 3 & 2 & 3 & 3 & 3 & 2 & 3 & 2 \\
\hline Process control & 1 & 3 & 3 & 3 & 3 & 3 & 2 & 1 & 2 & 1 & 1 & 1 & 2 & 2 & 3 & 2 & 5 & 2 & 2 & 3 \\
\hline Process performance management & 1 & 4 & 1 & 3 & 2 & 3 & 2 & 1 & 1 & 1 & 2 & 1 & 2 & 2 & 2 & 1 & 4 & 2 & 3 & 2 \\
\hline Process optimization & 2 & 4 & 3 & 2 & 3 & 3 & 3 & 1 & 2 & 2 & 2 & 2 & 2 & 3 & 3 & 3 & 4 & 3 & 2 & 2 \\
\hline Knowledge transfer \& IT & 2 & 2 & 3 & 3 & 4 & 3 & 3 & 3 & 2 & 2 & 2 & 1 & 2 & 3 & 3 & 3 & 3 & 2 & 3 & 2 \\
\hline Average score & 2 & 3 & 3 & 3 & 3 & 3 & 2 & 1 & 2 & 2 & 2 & 1 & 2 & 2 & 3 & 2 & 4 & 2 & 3 & 2 \\
\hline
\end{tabular}

Figure 4 graphically illustrates the operational excellence levels of the sales, sourcing, and manufacturing/production dimensions of the 20 companies considered in Table 5. The positions of the 20 companies are indicated on the outer circle. To create an overview of the 20 companies' operational excellence maturity, lines are used to connect the same indicator dimensions of different case companies. The blue line connects the scores for the sales dimension, the black line connects the scores for the sourcing dimension, and the grey line connects the scores for the manufacturing/production dimension.

The overall performance of the case companies is relatively low, with most receiving scores of 2 or 3 . In the sales dimension, the highest score was 3 for companies 2, 3, 4, 6, 16, 17, and 19. Only a couple of enterprises in the sourcing dimension received a score of 4 (companies 2 and 19). In the manufacturing dimension, case company 17 scored 4. 
Level 2 performance indicates that processes have begun to be defined but not yet at a systematic level. Process integrations have been initiated, but the main focus is to create a stable environment. At this level, process stabilization rather than continuous improvement is a priority. At level 3, processes are more documented, and metrics exist to assess process performance, which can then be used to improve processes. Process ownership has been defined, and information systems link the core processes.

The scores for sales, sourcing, and manufacturing/production and their indicators are quite similar, although the sales dimension received the lowest overall scores in the evaluation. Even so, notable differences are evident in the indicators corresponding to the order-delivery process.

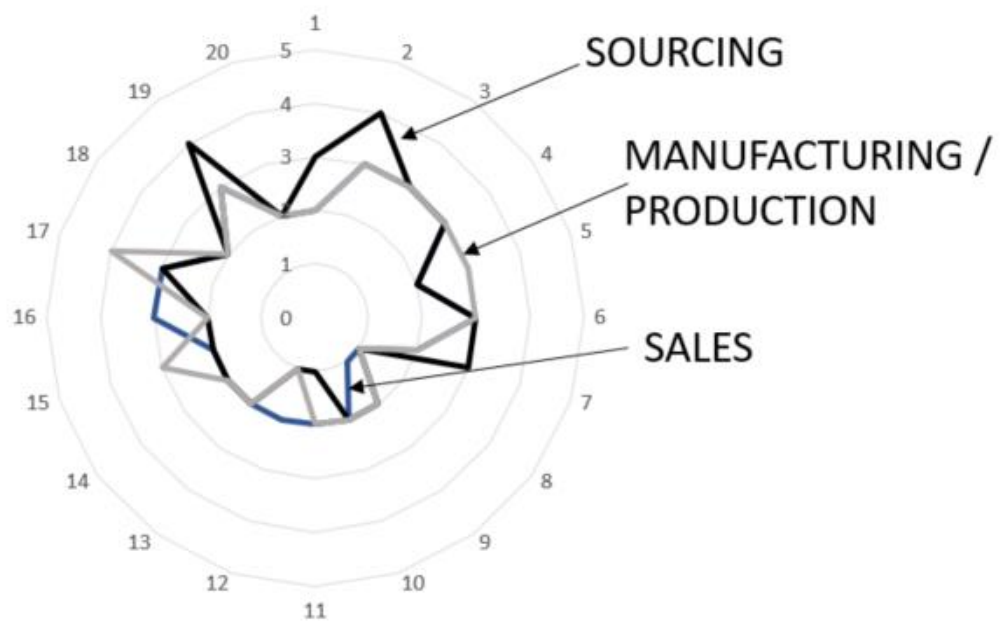

Figure 4: Operational excellence maturity review radar chart: operational excellence levels in sales (blue), sourcing (black), and manufacturing/production (grey)

\section{Discussion and implications}

The OEMR tool developed for the performance evaluation of microenterprises provided actionable and feasible results with respect to the operational excellence status of these enterprises. The indicators (three main indicators, each with six process factors) and the design of the tool considered the special circumstances of microenterprises, such as the lack of resources (especially development resources) and the small scale of operations. The actual performance evaluation was able to be completed in a short amount of time (approximately two hours), which was essential for engaging microenterprises in the performance evaluation process while still providing valid results that could be used as a baseline for operations development. This was seen as an essential capability for the tool based on previous research (e.g., Dutta and Evrard 1999; Töyli et al. 2008; Kelliher and Reinl 2009). Our research findings also support the need to take into consideration the microenterprises' context-specific requirements. The challenge, as stated by previous research, is to ensure sufficient starting knowledge of operations management and operational excellence so that interviews and discussions can be held at a level that ensures the reliability of the results and scores. 
The results show that the microenterprises in this study mostly received low scores on their operational excellence performance reviews. The 20 examined companies received the lowest scores in the sales process dimension. Thus, this dimension should be considered one of the most urgent areas in need of special attention. Nevertheless, the overall development of operations will be important for taking these enterprises' performance to the next level. These results can also provide the management of these enterprises with guidance on where development efforts should be focused.

Operational excellence could provide a competitive advantage that the microenterprises are not currently fully taking advantage of. The concept of operational excellence as a source of competitive advantage is based on the finding of Sadun, Bloom, and Van Reenen (2017) that operational excellence gives companies a sustainable competitive advantage, which correlates with long-term business performance. Tight global competition has intensified as a result of digital platforms and the generic digitalization of marketplaces; these have also lowered the barriers to market entry, which can expand the Nordic microenterprises' customer base. Yet these developments are also challenging microenterprises, such as those of the Nordic Arctic region, in their home markets, as this digitalization works in both directions, giving other companies easier access to the Nordic Artic region. Distance from customers is not such a significant barrier when companies' delivery platforms are digital. Even so, companies operating in the Nordic Arctic region must overcome high operation costs. Operational excellence can be one solution to this problem. Microenterprises need to systematically develop their processes and drive towards excellence in their operations.

Previous work by many scholars has focused on the development of operational excellence maturity models to suit the needs of larger enterprises (e.g., Hammer 2007; Fisher 2005; Harmon 2004). However, microenterprises are important drivers of the economy in the Nordic Arctic region and worthy of greater consideration. Microenterprises provide more than $90 \%$ of the jobs in this region and are the main source of new job creation and innovation. This study contributes to the development of an operational excellence evaluation tool that can be applied in the microenterprise context. The OEMR tool gives baseline metrics to understand the status of operations, and by using this tool, the most critical (with lowest maturity score) areas can be identified to give microenterprises guidance to make advised selections where to focus their development efforts to achieve greatest impact on operational performance in their resource constrained environment. This is generic challenge applicable also to other contexts. The future development of the OEMR tool needs to take into account the low level of operations management and understanding of operational excellence terminology in microenterprises. It also needs to address the maturity levels in a simplistic but still differentiating manner.

\section{Conclusion}

This study is one of the first in the Nordic context to assess operational excellence with microand small-sized enterprises as respondents. A significant amount of previous research has been performed in larger national, international, or global organizations. Therefore, this study contributes to the literature by revealing the operational excellence level of microenterprises, especially those operating in the Nordic Arctic environment. Although a relatively simple approach was used to investigate the level of operational excellence, the practical lessons learned shall still be translated to know-how when it is necessary to investigate the major areas that contribute to operational excellence improvements. 
Operational excellence was assessed using an operational excellence evaluation tool, the OEMR tool, which was tailor made to evaluate the operational excellence status of microenterprises based on the regional needs. This tool was developed to be efficient and easy to apply in the particular context of microenterprises. The study confirms that the developed tool was able to demonstrate actionable and feasible results that shall be used in operational excellence improvement initiatives in microenterprises. In particular, the tool assessed 20 microenterprises' baseline operational excellence status using the appropriate measures, thereby providing these enterprises with a suitable starting point for operational excellence development efforts. The results of the 20 companies considered as case studies show that their current operational excellence maturity level according to three dimensions (sales, sourcing, and manufacturing/production) is relatively low. The sales dimension of the companies' operations received the lowest score, but other areas are also in need of operational excellence enhancement efforts.

There is a growing demand to develop the operations management of microenterprises and SMEs in the Nordic Arctic region to enable them to be more competitive in the international market. Therefore, internationally comparable knowledge and education are essential, while entrepreneurs need to be trained/coached to enhance operational excellence. Operational excellence and efficient operations as well as growth and internationalization can be supported by creating and disseminating knowledge suitable for microenterprises and SMEs in the Nordic Arctic region. The ultimate objective of these efforts is to promote operational excellence based on competitive advantages.

Future research including a comprehensive survey can be carried out to identify key performance measures that enable the enhancement of the operational excellence of microenterprises and SMEs in the Nordic Arctic region.

\section{References}

Asif, M., O. A. M. Fisscher, E. J. de Bruijn, and M. Pagell. 2010. "Integration of Management Systems: A Methodology for Operational Excellence and Strategic Flexibility." Operational Management Research 3 (3-4): 146-160. doi:10.1007/s12063-010-0037-z.

Ayyagari, M., T. Beck, and A. Demirguc-Kunt. 2007. "Small and Medium Enterprises across the Globe." Small Business Economics 29 (4): 415-434.

Basu, R. 2004. Implementing Quality: A Practical Guide to Tools and Techniques: Enabling the Power of Operational Excellence. Cengage Learning EMEA, TJ International Ltd., Cornwall.

Becklund, F., D. Chronéer, and E. Sundqvist. 2014. "Project Management Maturity Models A Critical Review: A Case Study within Swedish Engineering and Construction Organizations." Procedia - Social and Behavioral Sciences 119: 837-846.

Bessant, J., S. Caffyn, and M. Gallagher. 2001. “An Evolutionary Model of Continuous Improvement Behaviour." Technovation 21: 67-77. 
Bischoff, C., and G. Wood. 2013. "Micro and Small Enterprises and Employment Creation: A Case Study of Manufacturing Micro and Small Enterprises in South Africa." Development Southern Africa 30 (4-5): 564-579.

Collins, J. 2006. "Where Are You on Your Journey from Good to Great? Good to Great Diagnostic Tool Version 1.00." Accessed November 10, 2017. http://www.jimcollins.com/tools/diagnostic-tool.pdf.

Cook, L. S., and R. Verma. 2002. "Exploring the Linkages between Quality System, Service Quality, and Excellence: Service Providers.” Quality Management Journal 9 (2): 44 56.

Cooke-Davies, T. J. 2004a. "Project Management Maturity Models". In The Wiley Guide to Managing Projects, edited by P.W.G. Morris and J. K. Pinto, 1234-1264. Hoboken, NJ: Wiley.

Cooke-Davies, T. J. 2004b. "Maturity and Measurement: What Are the Relevant Questions about Maturity and Metrics for a Project-Based Organization to Ask, and What Do They Imply for Project Management Research?” In Proceedings of the PMI Research Conference, London, UK.

Claudino, T. B., S. M. dos Santos, A. C. de Aquino Cabral, and M. N. M. Pessoa. 2017. "Fostering and Limiting Factors of Innovation in Micro and Small Enterprises." RAI Revista de Administração e Inovação 14 (2): 130-139.

Crawford, J. K. 2006. “The project management maturity model”. Information Systems Management, 23(4): 50-58.

Devins, D., J. Gold, S. Johnson, and R. Holden. 2005. "A Conceptual Model of Management Learning in Micro Businesses: Implications for Research and Policy.” Education+ Training 47 (8/9): 540-551.

Donovan, M. (2015). Lean Manufacturing: Performance Evaluation Audit. R. Michael Donovan \& Co., Inc., www.rmdonovan.com (accessed 03.2015).

Dutta, S., and P. Evrard. 1999. "Information Technology and Organisation within European Small Enterprises.” European Management Journal 17 (3): 239-251.

Evans, J. R., and E. P. Jack. 2003. "Validating Key Results Linkages in the Baldrige Performance Excellence Model.” The Quality Management Journal 10 (2): 7.

Fisher, D. 2005. "Getting Started on the Path to Process-Driven Enterprise Optimization." BPTrends.

Gleich, R., and R. Sauter. 2008. Operational Excellence: Innovative ansätze und best practices in der produzierenden industrie [Innovative approaches and best practices in the production industry]. München: Rudolf Haufe Verlag GmbH \& Co. KG.

Goodson, R. E. 2002. "Read a Plant - Fast.” Harvard Business Review 3-11. https://hbr.org/2002/05/read-a-plant-fast (accessed on 10.01.2018). 
Grimm, M., and A. L. Paffhausen. 2015. "Do Interventions Targeted at Micro-Entrepreneurs and Small and Medium-Sized Firms Create Jobs? A Systematic Review of the Evidence for Low and Middle Income Countries.” Labour Economics 32: 67-85.

Gunasekaran, A., R. E. McGaughey, E. W. T. Ngai, and B. K. Rai. 2009. "E-Procurement Adoption in the Southcoast SMEs." International Journal of Production Economics 122 (1): 161-175.

EFQM. 2012. "An Overview of the EFQM Excellence Model.” Accessed November 10, 2017. http://www.efqm.org/sites/default/files/overview_efqm_2013_v1.pdf.

Eurolex. 2003. "Commission Recommendation of 6 May 2003 Concerning the Definition of Micro, Small and Medium-Sized Enterprises." Official Journal of the European Union L 124: 36-41.

Finland University Act. 2009. http://www.finlex.fi/fi/laki/ajantasa/2009/20090558.

Hadjimanolis, A., G. Boustras, A. Economides, A. Yiannaki, and L. Nicolaides. 2015. "Work Attitudes and Safety Performance in Micro-Firms - Results from a Nationwide Survey (the Opinion of the Employees).” Safety Science 80: 135-143.

Hammer, M. 2007. “The Process Audit.” Harvard Business Review 85: 111-123.

Harmon, P. 2004. "Evaluating an Organization's Business Process Maturity.” Business Process Trends 2 (3): 1-11.

Hausman, A. 2005. "Innovativeness among Small Businesses: Theory and Propositions for Future Research.” Industrial Marketing Management 34 (8): 773-782.

Hutchings, G. 2001. “CMM Lessons Learned.” PMNetwork, 15(6): 21.

Isoherranen, V., E. R. Niinikoski, T. Malinen, M. Jokinen, P. Kess, and M. K. Karkkainen. 2016. "Operational Excellence Evaluation Model for SMEs and Regional Findings." Paper presented at the IEEE 2016 International Conference on Industrial Engineering and Engineering Management, Bali, Indonesia, December 5-7.

Jaeger, A., K. Matyas, and W. Sihn. 2014. "Development of an Assessment Framework for Operations Excellence (OsE), Based on the Paradigm Change in Operational Excellence (OE)." Procedia CIRP 17: 487-492.

Kaufman, C. 2007. "Financing SMEs in South Africa." OECD Development Centre Policy Insights 7: 1-4.

Kayrbekova, D. 2011. “Activity-Based Life-Cycle Cost Analysis: Design, Operation and Maintenance in Arctic Environment." PhD diss., University of Stavanger, Norway.

Kelliher, F., and L. Reinl. 2009. "A Resource-Based View of Micro-Firm Management Practice.” Journal of Small Business and Enterprise Development 16 (3): 521-532. 
Knowledge Foundation. 2003. "Organizational Project Management Maturity Model (OPM3)."

http://faculty.kfupm.edu.sa/MGM/bubshait/project\%20management/PDF/opm3KF.pd f.

Kobayashi, I. 1995. 20 Keys to Workplace Improvement. Portland: Productivity Press.

Koomen, T., and M. Pol. 1998. "Improvement of the Test Process Using TPI.” Accessed November 10, 2017. https://itq.ch/pdf/tpi/tpi_uk.pdf.

Lockamy, A., III, and K. McCormack. 2004a. "Linking SCOR Planning Practices to Supply Chain Performance: An Exploratory Study." International Journal of Operations \& Production Management 24 (12): 1192-1218.

Lockamy, A., III, and K. McCormack. 2004b. "The Development of a Supply Chain Management Process Maturity Model Using the Concepts of Business Process Orientation." Supply Chain Management: An International Journal 9 (4): 272-278.

MBOA. 2016. "The Malcolm Baldrige Criteria for Performance Excellence." Accessed November 10, 2017. http://www.nist.gov/baldrige/publications/business_nonprofit_criteria.cfm.

Miller, R. 2014. The Shingo Model Handbook for Operational Excellence. Accessed November 10, 2017. http://lean.nh.gov/documents/Shingo\%20Model\%20Handbook.pdf.

Morash, E. A., and R. S. Clinton. 1998. "Supply Chain Integration: Customer Value through Collaborative Closeness versus Operational Excellence." Journal of Marketing Theory and Practice 6 (4): 104-120. doi:10.1080/10696679.1998.11501814.

Nesensohn, C., D. Bryde, E. Ochieng, D. Fearon, and V. Hackett. 2014. "Assessing Lean Construction Maturity." Proceedings IGLC-22 1157-1168. https://iglcstorage.blob.core.windows.net/papers/attachment-9cab56ae-5e60-49e9ae40-1d07c1ba7802.pdf (accessed on 10.01.2018).

Nightingale, D. 2005. "LESAT: The Lean Enterprise Self-Assessment Tool." ESD.61J / 16.852: Integrating the Lean Enterprise. https://ocw.mit.edu/courses/aeronautics-andastronautics/16-852j-integrating-the-lean-enterprise-fall-2005/lecturenotes/13_lesat.pdf (accessed on 10.01.2018).

Nightingale, D. J., and J. H. Mize. 2002. "Development of a Lean Enterprise Transformation Maturity Model." Information Knowledge Systems Management 3: 15-30.

Novaczek, I., and E. K. Stuart. 2006. "The Contribution of Women Entrepreneurs to the Local Economy in Small Islands: Seaplant-Based Micro-Enterprise in Fiji and Vanuatu." Journal of Small Business \& Entrepreneurship 19 (4): 367-379.

Oakland, J. S. 2014. Total Quality Management and Operational Excellence: Text with Cases. New York, Routledge. 
Olhager, J., and F. Persson. 2006. "Simulating Production and Inventory Control Systems: A Learning Approach to Operational Excellence." Production Planning \& Control 17 (2): 113-127.

Olsen, L. S., A. Berlina, L. Jungsberg, N. Mikkola, J. Roto, R. O. Rasmussen, and A. Karlsdottìr. 2016. "Sustainable Business Development in the Nordic Arctic." Nordregio Working Paper 1. Stockholm.

Parinduri, R. A. 2014. "Family Hardship and the Growth of Micro and Small Firms in Indonesia." Bulletin of Indonesian Economic Studies 50 (1): 53-73.

P3M3-OGC. 2006. "Portfolio, Programme \& Project Management Maturity Model (P3M3), Version 1.0." https://www.projectsmart.co.uk/docs/p3m3.pdf (accessed on 10.01.2018).

Porter, M. E. (1996). What is strategy. Published November.

Ratnayake, R. M. C. 2016. "Asset Integrity Assessment and Control of Operating Assets in Arctic Environment: Assuring Sustainable Performance." Paper presented at the 26th International Ocean and Polar Engineering Conference for the International Society of Offshore and Polar Engineers, Rhodes, Greece, June 26-July 2. Accessed June 20, 2017. https://www.onepetro.org/conference-paper/ISOPE-I-16-196.

Ray, C.D., X. Zuo, J.H. Michael, J.K. Wiedenbeck. 2006. "The Lean Index: Operational "Lean" Metrics for The Wood Products Industry", Wood and Fiber Science, 38: 238255.

Roberts, M., and M. Wood. 2002. "The Strategic Use of Computerised Information Systems by a Micro Enterprise." Logistics Information Management 15 (2): 115-125.

Sadun, R., N. Bloom, and J. Van Reenen. 2017. "Why Do We Undervalue Competent Management? Great Leadership and Brilliant Strategy Won't Succeed Without Operational Excellence." Harvard Business Review 95 (5): 120-127.

Schlichter, J. and Duncan, W. R. (1999). “An organizational PM maturity model. PM Network", 13(2): 18.

Sembiring, M. 2008. "SMEs Growth and Development in Indonesia." Paper presented at the Joint Regional Workshop on SME Development and Regional Economic Integration, Tokyo, September 22-26.

Simmonds, S. 2009. "Data Provisioning: A New Paradigm.” Accessed November 12, 2017. https://datatechnology. wordpress.com/2009/04/07/hello-world/.

Sutton, D. 2011. Back to Basics: A Practitioner's Guide to Operations Excellence. Cincinnati, Operations Excellence Services.

Söderberg, L., and L. Bengtsson. 2010. "Supply Chain Management Maturity and Performance in SMEs." Operations Management Research 3 (1-2): 90-97. 
Taneja, S., M. G. Pryor, and M. Hayek. 2016. "Leaping Innovation Barriers to Small Business Longevity.” Journal of Business Strategy 37 (3): 44-51.

Treacy, M., and F. Wiersema. 1993. "Customer Intimacy and Other Value Disciplines." Harvard Business Review 71 (1): 84-93.

Töyli, J., L. Häkkinen, L. Ojala, and T. Naula. 2008. "Logistics and Financial Performance: An Analysis of 424 Finnish Small and Medium-Sized Enterprises." International Journal of Physical Distribution \& Logistics Management 38 (1): 57-80.

World Bank. 2012. World Development Report 2013: Jobs. World Bank, Washington DC.

World Bank. 2013. Doing Business 2014: Understanding Regulations for Small and MediumSize Enterprises. Washington, DC: World Bank Group.

Yin, R. K. 2009. Case Study Research: Design and Methods. Los Angeles, CA: Sage.

Yrittäjät, S. 2017. “The Small and Medium-Sized Enterprises.” Accessed March 27, 2017. https://www.yrittajat.fi/en/about-federation-finnish-enterprises/small-and-mediumsized-enterprises-526261. 